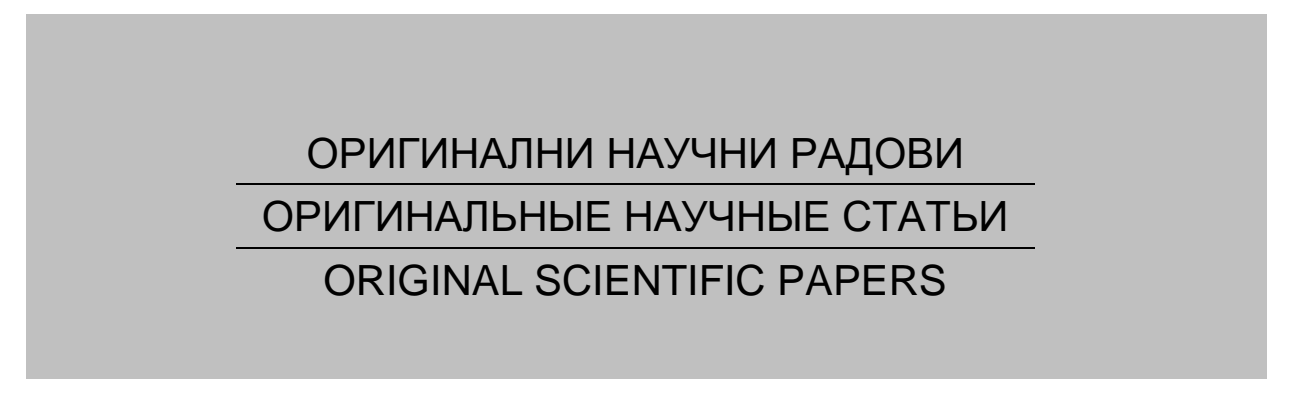

\title{
APPLICATION OF PROBABILITY-BASED MULTI-OBJECTIVE OPTIMIZATION IN MATERIAL ENGINEERING
}

\author{
Maosheng Zheng \\ Northwest University, School of Chemical Engineering, \\ Xi'an, People's Republic of China, \\ e-mail:mszhengok@aliyun.com, \\ ORCID iD: (https://orcid.org/0000-0003-3361-4060
}

DOI: 10.5937/vojtehg70-35366; https://doi.org/10.5937/vojtehg70-35366

FIELD: Mathematics, Materials

ARTICLE TYPE: Original scientific paper

Abstract:

Introduction/purpose: Althought many methods have been proposed to deal with the problem of material selection, there are inherent defects of additive algorithms and subjective factors in such algorithms. Recently, a probability-based multi-objective optimization was developed to solve the inherent shortcomings of the previous methods, which introduces a novel concept of preferable probability to reflect the preference degree of the candidate in the optimization. In this paper, the new method is utilized to conduct an optimal scheme of the switching material of the RF-MEMS shunt capacitive switch, the sintering parameters of natural hydroxyapatite and the optimal design of the connecting claw jig.

Methods: All performance utility indicators of candidate materials are divided into two groups, i.e., beneficial or unbeneficial types for the selection process; each performance utility indicator contributes quantitatively to a partial preferable probability and the product of all partial preferable probabilities makes the total preferable probability of a candidate, which transfers a multi-objective optimization problem into a single-objective optimization one and represents a uniquely decisive index in the competitive selection process.

Results: $\mathrm{Cu}$ is the appropriate material in the material selection for RF MEMS shunt capacitive switches; the optimal sintering parameters of natural hydroxyapatite are at $1100^{\circ} \mathrm{C}$ and 0 compaction pressure; and the optimal scheme is scheme No 1 for the optimal design of a connecting claw jig. 


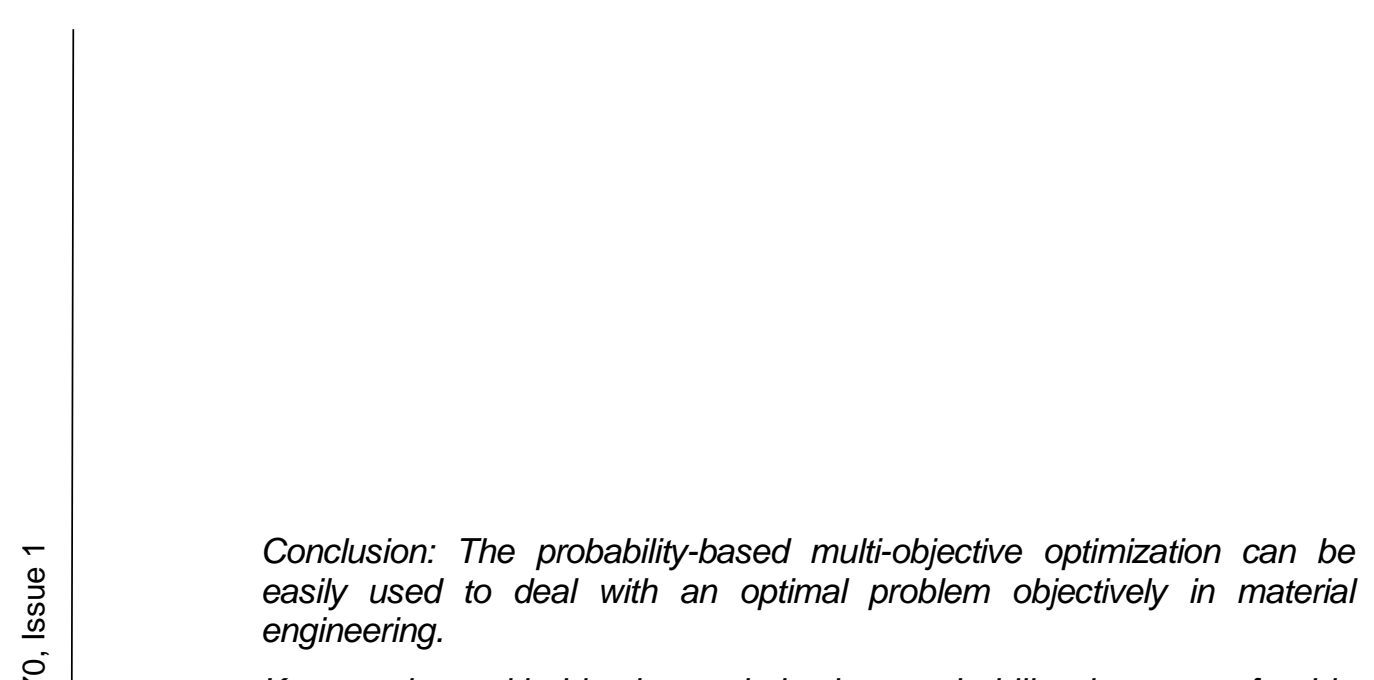

Key words: multi-objective optimization, probability theory, preferable probability, material engineering, scheme selection.

\section{Introduction}

It has been more than 40 years (Ashby, 2000) since early works in material selection appeared; many methods have been proposed to analyze a big amount of data involved in the material selection process so as to obtain an appropriate result.

Various algorithms (techniques) have been developed, including Ashby's method (Ashby, 2000; Ashby et al, 2004), Technique for Order Preference by Similarity to Ideal Solution (TOPSIS), VIse Kriterijumska Optimizacija Kompromisno Resenje (VIKOR), Multi Attribute Decision Making (MADM), Analytical Hierarchy Process (AHP), Simple Additive Weighted (SAW) method and Multi-Objective Optimization on the basis of Ratio Analysis (MOORA), etc (Zheng et al, 2021). Ashby's method is difficult to be applied in cases which involve multiple criteria of selection (Ashby, 2000; Ashby et al, 2004; Zheng et al, 2021). Deshmukh et al employed the multi-objective optimization (MOO) techniques of TOPSIS and VIKOR to perform the material selection of the switching structure for RE-MEMS shunt capacitive switches (Deshmukh \& Angira, 2019). However, there exist inherent problems of additive algorithms and subjective factors in the MADM, AHP, MOORA, TOPSIS and VIKOR due to their fatal scaling or normalization processes (Zheng et al, 2021).

Recently, a new probability-based multi-objective optimization method was developed (Zheng et al, 2021), attempting to solve the inherent problems of personal and subjective factors in the previous multi-objective optimization methods. The novel concept of preferable probability was introduced to reflect the preference degree of a candidate in the optimization where all performance utility indicators of candidates are divided into beneficial or unbeneficial types for the selection. Each performance utility indicator of a candidate contributes to a partial preferable probability quantitatively, and the total preferable probability of a candidate is the product of all partial preferable probabilities from the viewpoint of the probability theory, which is the overall and unique decisive index in the competitive selection process. The new multiobjective optimization method was also extended with the application of the multi-objective orthogonal test design method (OTDM) and the 
uniform test design method (UTDM), which results in appropriate achievements (Zheng et al, 2021).

In this paper, the new probability-based multi-objective optimization method is used to perform the optimal scheme in material engineering, which includes the selection of switching material of the RF-MEMS shunt capacitive switch, the optimization of the sintering parameters of natural hydroxyapatite and the optimal design of a connecting claw jig.

\section{Brief introduction to the new multi-objective optimization method}

In the new probability-based multi-objective optimization method (Zheng et al, 2021), a beneficial utility index of material performance indicator contributes to a partial preferable probability in a positively linear manner, i.e.,

$$
P_{i j}=\alpha_{i j} X_{i j}, i=1,2, \ldots, n ; j=1,2, . . m .
$$

In Eq. (1), $X_{i j}$ is the $f^{\text {th }}$ beneficial utility index of the material performance indicator of the $i^{\text {th }}$ candidate material; $P_{i j}$ represents the partial preferable probability of the beneficial utility index $X_{i j} ; n$ is the total number of candidate materials in the material group involved; $m$ is the total number of the utility indices of each candidate material in the group; $\alpha_{j}$ is the normalized factor of the $j^{\text {th }}$ utility index of the material performance indicator, $\alpha_{i j}=1 /\left(n \bar{X}_{j}\right)$, and $\bar{X}_{j}$ is the arithmetic mean value of the utility index of the material performance indicator in the material group involved.

Equivalently, the unbeneficial utility index of the material performance indicator contributes to a partial preferable probability in a negatively linear manner, i.e.,

$$
P_{i j}=\beta_{i j}\left(X_{j \max }+X_{j \min }-X_{i}\right), i=1,2, \ldots, n ; j=1,2, . . m .
$$

In Eq. (3), $X_{j \max }$ and $X_{j \min }$ represent the maximum and minimum values of the utility indices $X_{j}$ of the material performance indicator in the material group, respectively, and $\beta_{j}$ is the normalized factor of the $j^{\text {th }}$ utility indices of the material performance indicator, $\beta_{i j}=1 /\left[n\left(X_{j \min }+X_{j \max }\right)-n \bar{X}_{j}\right]$.

Moreover, the total / comprehensive preferable probability of the $i^{\text {th }}$ candidate material is the product of its partial preferable probability $P_{i j}$ of each utility index of the material performance indicator in the overall 
selection due to the "simultaneous optimization" of the multi-objects in the viewpoint of probability theory (Zheng et al, 2021), i.e.,

$$
P_{i}=P_{i 1} \cdot P_{i 2} \cdots P_{i m}=\prod_{j=1}^{m} P_{i j} .
$$

The total preferable probability of a candidate is the uniquely decisive index in the overall selection process competitively, which transfers a multi-objective optimization problem (MOOP) into a single objective optimization one. The main characteristic of the new probabilitybased multi-objective optimization is that the treatment for both beneficial utility index and unbeneficial utility index is equivalent and conformable, which is without any artificial or subjective scaling factors involved in the process.

\section{Application of probability-based multi-objective} optimization in material engineering

\section{1) Multi-objective optimization in the material selection of RF-MEMS shunt capacitive switches}

Radio Frequency Micro Electro Mechanical Systems (RF-MEMS) is a promising technology for implementing passive devices in future wireless communication systems (Deshmukh \& Angira, 2019). Switches have drawn more attention due to their frequent use in many cases in wireless communication systems. An RF-MEMS technology-based switch has low insertion loss, high isolation, high linearity and less power consumption (Deshmukh \& Angira, 2019). Its shunt capacitive switch has two stable states i.e., up-state and down-state (Deshmukh \& Angira, 2019). Power can flow from the input port to the output port in the switch upstate, while it stands at the off-state in its down-state (Deshmukh \& Angira, 2019; Angira \& Rangra, 2015a; Angira \& Rangra, 2015b).

The optimization of the performance of the switching structure involves many parameters (criteria), such as pull-in voltage, RF response (insertion loss and isolation), maximum displacement, thermal conductivity, etc (Deshmukh \& Angira, 2019; Angira \& Rangra, 2015a; Angira \& Rangra, 2015b). Since many parameters are involved, it can be seen as a MOOP in the performance optimization of the switching material selection. Therefore, a MOOP can be used to decrease human effort since a large number of materials are available in practice, forming a material bank together with many manufacturing processes and selection attributes (Zheng et al, 2021). 
Yang et al pointed out that if different normalization methods are applied, significant different results may be produced (Yang et al, 2021). Podviezko et al also stressed that different normalization of data applying to popular MCDM methods such as SAW or TOPSIS could lead to significant differences in the assessment (Podviezko \& Podvezko, 2015). As a consequence, many researchers paid a lot of attention to the choice of the normalization type. However, it is still puzzling which normalization method is better and how to determine final results of material selection from different normalization algorithms.

A) Utility indices of the material performance indicators in the material selection of RF - MEMS shunt capacitive switches

In the study of Deshmukh \& Angira (2019), the optimal objectives for this purpose are low pull-in voltage, low RF loss, high thermal conductivity and maximum displacement of the beam structure. As a result, the square root of Young's modulus of the material $E^{0.5}$, the electrical resistive coefficient $\rho_{e}$, the thermal conductivity of the material $\lambda$, the ratio of the fracture strength $\sigma_{f}$ to Young's modulus $E$ of the material, $\sigma f E$, are taken as the optimal utility indices of the material attribute indicators (Deshmukh \& Angira, 2019).

B) Divisions of the utility indices in the material selection of RF - MEMS shunt capacitive switches

From analyzing the requirements of the optimizations of the bridge of RF-MEMS shunt capacitive switches, i.e., higher pull-in voltage $\left(V_{p}\right)$, lower RF loss, higher thermal conductivity and the higher maximum displacement of the switch beam (Deshmukh \& Angira, 2019), the utility indices of the square root of Young's modulus of the material, $E^{0.5}$, the thermal conductivity of the material, $\lambda$, the ratio of the fracture strength $\sigma_{f}$ to Young's modulus $E$ of the material, $\sigma_{t} / E$, belong to the beneficial type of the material performance index, while the electrical resistive coefficient, $\rho_{e}$, belongs to the unbeneficial type of the material performance index in the assessment.

C) Assessment results

The values of the conventional material performance indicators for various materials are given in Table 1 (Deshmukh \& Angira, 2019).

The partial preferable probabilities of the utility indices of $E^{0.5}, \lambda$ and $\rho_{e}$ and $\sigma_{f} / E$ and the total preferable probabilities are assessed according to Equations (1) through (5), respectively, shown in Table 2. In addition, 
the ranking here by using the new probability-based multi-objective optimization method is given in Table 2 together with those of Vikor and Topsis from Ref. (Deshmukh \& Angira, 2019) for comparison.

Table 1 - Conventional material performance indicators for various materials (Deshmukh \& Angira, 2019)

Таблица 1 - Стандартные показатели эфрфективности материалов для различных материалов (Deshmukh \& Angira, 2019)

Табела 1 - Индикатори уобичајених перформанси материјала за различите материјале (Deshmukh \& Angira, 2019)

\begin{tabular}{|c|c|c|c|c|c|}
\hline Mat. & $\begin{array}{c}\text { Young's } \\
\text { modulus } \\
E(\mathrm{GPa})\end{array}$ & $\begin{array}{c}\text { Electrical } \\
\text { resistive } \\
\text { coefficient } \\
\rho_{e}(\Omega \mathrm{m}) 10^{-8}\end{array}$ & $\begin{array}{c}\text { Thermal } \\
\text { conductivity } \\
\lambda(\mathrm{W} / \mathrm{m} \cdot \mathrm{K})\end{array}$ & $\begin{array}{c}\text { Fracture } \\
\text { strength } \\
\sigma(\mathrm{MPa})\end{array}$ & $\begin{array}{c}(\sigma / \mathrm{E}) \\
\times 10^{3}\end{array}$ \\
\hline $\mathrm{Ni}$ & 193 & 6.99 & 90 & 345 & 1.7876 \\
\hline $\mathrm{Au}$ & 70 & 2.44 & 315 & 220 & 3.1429 \\
\hline $\mathrm{Al}$ & 70 & 2.82 & 204 & 47 & 0.6714 \\
\hline $\mathrm{Ag}$ & 83 & 1.59 & 407 & 110 & 1.3253 \\
\hline $\mathrm{Pt}$ & 168 & 10.5 & 73 & 125 & 0.7440 \\
\hline $\mathrm{Cu}$ & 117 & 1.68 & 386 & 314 & 2.6838 \\
\hline $\mathrm{Cr}$ & 279 & 12.9 & 90 & 370 & 1.3262 \\
\hline $\mathrm{W}$ & 411 & 5.28 & 163 & 1725 & 4.1971 \\
\hline $\mathrm{Co}$ & 209 & 6.24 & 69 & 675 & 3.2297 \\
\hline $\mathrm{Fe}$ & 211 & 9.61 & 73 & 540 & 2.5592 \\
\hline
\end{tabular}

Table 2 - Partial preferable probabilities and total preferable probabilities for various materials for shunt capacitive switch optimization

Таблица 2 - Частичные предпочтительные вероятности и общие предпочтительные вероятности для различных материалов при оптимизации емкостного шунтирующего переключателя

Табела 2 - Делимичне пожељне вероватноће и укупне пожељне вероватноће за различите материјале у оптимизацији капацитивног прекидача шанта

\begin{tabular}{|c|c|c|c|c|c|c|c|c|}
\hline Mat. & $P_{E^{\wedge} 0.5}$ & $P_{\rho e}$ & $P_{\lambda}$ & $P_{\text {of/E }}$ & $P_{t \times 10^{4}}$ & $\begin{array}{c}\text { Rank } \\
\text { here }\end{array}$ & $\begin{array}{c}\text { Rank } \\
\text { Vikor }\end{array}$ & $\begin{array}{c}\text { Rank } \\
\text { Topsis }\end{array}$ \\
\hline $\mathrm{Ni}$ & 0.1073 & 0.0884 & 0.0481 & 0.0825 & 0.3766 & 6 & 6 & 6 \\
\hline $\mathrm{Au}$ & 0.0646 & 0.1420 & 0.1684 & 0.1451 & 2.2423 & 3 & 1 & 1 \\
\hline $\mathrm{Al}$ & 0.0646 & 0.1375 & 0.1091 & 0.0310 & 0.3005 & 7 & 4 & 4 \\
\hline $\mathrm{Ag}$ & 0.0704 & 0.1520 & 0.2176 & 0.0612 & 1.4242 & 4 & 3 & 3 \\
\hline $\mathrm{Pt}$ & 0.1001 & 0.0470 & 0.0390 & 0.0343 & 0.0631 & 10 & 8 & 9 \\
\hline $\mathrm{Cu}$ & 0.0835 & 0.1510 & 0.2064 & 0.1239 & 3.2248 & 1 & 2 & 2 \\
\hline $\mathrm{Cr}$ & 0.1290 & 0.0187 & 0.0481 & 0.0612 & 0.0712 & 9 & 10 & 10 \\
\hline $\mathrm{W}$ & 0.1566 & 0.1085 & 0.0872 & 0.1937 & 2.8697 & 2 & 9 & 7 \\
\hline $\mathrm{Co}$ & 0.1117 & 0.0972 & 0.0369 & 0.1490 & 0.5971 & 5 & 5 & 5 \\
\hline $\mathrm{Fe}$ & 0.1122 & 0.0575 & 0.0390 & 0.1181 & 0.2975 & 8 & 7 & 8 \\
\hline
\end{tabular}


It can be seen from Table 2 that the appropriate material from the new multi-objective optimization method is $\mathrm{Cu}$, which is different from those of Vikor and Topsis from (Deshmukh \& Angira, 2019); this is because of the inherent defects of personal and subjective factors in Vikor and Topsis (Deshmukh \& Angira, 2019).

In fact, the evaluation result of the new probability-based method for multi-objective optimization in material selection is no need to equal to those of other previous approaches exactly due to their involvements of personal or other subjective coefficients.

\section{2) Optimization of sintering parameters of natural hydroxyapatite}

Abifarin conducted the optimization of hydroxyapatite (HAp) mechanical characteristics using Taguchi grey relational analysis design which includes hardness and compressive strength (Abifarin, 2021). Three levels of sintering temperature and two levels of compaction pressure are employed during sintering (Abifarin, 2021). The design and the results are shown in Table 3 . Again, the probability-based multiobjective optimization is used to conduct the assessment with hardness and compressive strength as the beneficial type index. The evaluation results are shown in Table 4.

Table 3 - Design and the results of HAp

Таблица 3 - Разработка и результаты гидроксиапатита

Табела 3 - Пројектовање и резултати хидроксиапатита

\begin{tabular}{|c|c|c|c|c|}
\hline No & Pressure & $\begin{array}{c}\text { Temperature } \\
{ }^{\circ} \mathrm{C}\end{array}$ & Hardness & $\begin{array}{c}\text { Compressive } \\
\text { Strength }\end{array}$ \\
\hline 1 & 0 & 900 & 0.54 & 0.39 \\
\hline 2 & 0 & 1000 & 0.838 & 0.58 \\
\hline 3 & 0 & 1100 & 0.940 & 0.84 \\
\hline 4 & 5 & 900 & 0.656 & 0.34 \\
\hline 5 & 5 & 1000 & 0.929 & 0.5 \\
\hline 6 & 5 & 1100 & 1.103 & 0.69 \\
\hline
\end{tabular}

Table 4 - Evaluation results of $H A p$

Таблица 4 - Результаты оценки гидроксиапатита

Табела 4 - Резултати оцене хидроксиапатита

\begin{tabular}{|c|c|c|c|c|}
\hline & \multicolumn{2}{|c|}{ Partial preferable probability } & \multicolumn{2}{c|}{ Total } \\
\hline No & Hardness & Strength & $\mathrm{Pt}^{*} 10^{2}$ & Rank \\
\hline 1 & 0.1079 & 0.1168 & 1.2596 & 6 \\
\hline 2 & 0.1674 & 0.1737 & 2.9069 & 3 \\
\hline 3 & 0.1878 & 0.2515 & 4.7225 & 1 \\
\hline 4 & 0.1311 & 0.1018 & 1.3340 & 5 \\
\hline 5 & 0.1856 & 0.1497 & 2.7781 & 4 \\
\hline 6 & 0.2203 & 0.2066 & 4.5518 & 2 \\
\hline
\end{tabular}


Table 4 indicates that the optimal sintering parameters of natural hydroxyapatite are at $1100^{\circ} \mathrm{C}$ and 0 compaction pressure.

\section{3) Optimal design of a connecting claw jig}

Yan et al conducted the multi-objective optimal design of a connecting claw jig with ANSYS Workbench finite element analysis software (Yan et al, 2021). The maximum equivalent stress (MPa) $Y_{1}$, the weight $(\mathrm{kg}) Y_{2}$, the minimum safety factor $Y_{3}$ and the maximum deformation $(\mathrm{mm}) Y_{4}$ of the claw jig are taken as the optimization objectives, while the thickness of the substrate $\mathrm{FD}_{1}(\mathrm{~mm}) x_{1}$, the angle of the connecting claw $\mathrm{A} 1\left(^{\circ}\right) x_{2}$, the thickness of the connecting claw $\mathrm{FD}_{2}$ $(\mathrm{mm}) x_{3}$, and the outside diameter of the jig base $R_{1}(\mathrm{~mm}) x_{4}$ are taken as the input variables.

After the simulation and the analysis, three candidate schemes with good objective functions are selected by the system, as shown in Table 5. The object $Y_{3}$ is a beneficial type index, while $Y_{1}, Y_{2}$ and $Y_{4}$ are all unbeneficial type indexes. The evaluation results are shown in Table 6.

Table 6 shows that the optimal scheme is scheme No 1.

Table 5 - Three candidate schemes of the connecting claw jig

Таблица 5 - Три возможные схемы кулачковой муфрты

Табела 5 - Шеме три кандидата за канцасту спојницу

\begin{tabular}{|c|c|c|c|c|c|c|c|c|}
\hline \multirow{2}{*}{$\begin{array}{c}\text { Original } \\
\text { scheme }\end{array}$} & $\begin{array}{c}\mathrm{X}_{1} \\
(\mathrm{~mm})\end{array}$ & $\mathrm{X}_{2}\left({ }^{\circ}\right)$ & $\begin{array}{c}\mathrm{X}_{3} \\
(\mathrm{~mm})\end{array}$ & $\begin{array}{c}\mathrm{X}_{4} \\
(\mathrm{~mm})\end{array}$ & $\begin{array}{c}\mathrm{Y}_{1} \\
(\mathrm{MPa})\end{array}$ & $\begin{array}{c}\mathrm{Y}_{2} \\
(\mathrm{~kg})\end{array}$ & $\mathrm{Y}_{3}$ & $\begin{array}{c}\mathrm{Y}_{4} \\
(\mathrm{~mm})\end{array}$ \\
\cline { 2 - 9 } & 56 & 79 & 38 & 32.5 & 151.22 & 6.176 & 1.6532 & 1.171 \\
\hline 1 & 54.125 & 73.13 & 35.414 & 31.051 & 128.42 & 5.615 & 1.9467 & 0.923 \\
\hline 2 & 48.125 & 73.77 & 37.982 & 32.395 & 143.31 & 5.577 & 1.7444 & 1.043 \\
\hline 3 & 46.625 & 76.38 & 39.908 & 30.715 & 161.48 & 5.620 & 1.5482 & 1.375 \\
\hline
\end{tabular}

Table 6 - Evaluation results of the connecting claw jig

Таблица 6 - Результаты оценки кулачковой муфты

Табела 6-Резултати оцена канцасте спојнице

\begin{tabular}{|c|c|c|c|c|c|c|}
\hline \multirow{2}{*}{ No. } & \multicolumn{3}{|c|}{ Partial preferable probability } & \multicolumn{2}{c|}{ Total } \\
\cline { 2 - 7 } & $\mathrm{Y}_{1}$ & $\mathrm{Y}_{2}$ & $\mathrm{Y}_{3}$ & $\mathrm{Y}_{4}$ & $\mathrm{Pt}^{*} 100$ & Rank \\
\hline 1 & 0.3700 & 0.3327 & 0.3716 & 0.3870 & 1.7697 & 1 \\
\hline 2 & 0.3358 & 0.3349 & 0.3329 & 0.3532 & 1.3229 & 2 \\
\hline 3 & 0.2942 & 0.3324 & 0.2955 & 0.2598 & 0.7507 & 3 \\
\hline
\end{tabular}




\section{Conclusion}

The application of the new probability-based multi-objective optimization method in dealing with three optimal problems of material engineering has shown that: the appropriate material $(\mathrm{Cu})$ is successfully selected, which meets the requirements of the optimizations of the bridge of RF - MEMS shunt capacitive switches; the optimal sintering parameters of natural hydroxyapatite are at $1100^{\circ} \mathrm{C}$ and 0 compaction pressure; and the optimal scheme of the connecting claw jig is scheme No 1. The main feature of the new probability-based multi-objective optimization method is that the treatment is equivalent and conformable for both the beneficial utility index and the unbeneficial utility index, without any artificial or subjective scaling factors involved in the process.

\section{References}

Abifarin, J.K. 2021 Taguchi grey relational analysis on the mechanical properties of natural hydroxyapatite: effect of sintering parameters. The International Journal of Advanced Manufacturing Technology, 117, pp.49-57. Available at: https://doi.org/10.1007/s00170-021-07288-9.

Angira, M. \& Rangra, K. 2015a. Design and investigation of a low insertion loss, broadband, enhanced self and hold down power RF-MEMS switch. Microsystem Technologies, 21(6), pp.1173-1178. Available at: https://doi.org/10.1007/s00542-014-2188-6.

Angira, M. \& Rangra, K. 2015b. Performance improvement of RF-MEMS capacitive switch via asymmetric structure design. Microsystem Technologies, 21(7), pp.1447-1452. Available at: https://doi.org/10.1007/s00542-014-2222-8.

Ashby, M.F. 2000. Multi-Objective optimization in material design and selection. Acta Materialia, 48(1), pp.359-369. Available at: https://doi.org/10.1016/S1359-6454(99)00304-3.

Ashby, M.F., Bréchet, Y.J.M., Cebon, D. \& Salvo, L. 2004. Selection strategies for materials and processes. Materials \& Design, 25(1), pp.51-67. Available at: https://doi.org/10.1016/S0261-3069(03)00159-6.

Deshmukh, D. \& Angira, M. 2019. Investigation on Switching Structure Material Selection for RF-MEMS Shunt Capacitive Switches Using Ashby, TOPSIS and VIKOR. Transactions on Electrical and Electronic Materials, 20, pp.181-188. Available at: https://doi.org/10.1007/s42341-018-00094-3.

Podviezko, A. \& Podvezko, V. 2015. Influence of data transformation on multicriteria evaluation result. Procedia Engineering, 122, pp.151-157. Available at: https://doi.org/10.1016/j.proeng.2015.10.019.

Yan, Y., Fu, N., Zhang, X., Wang, C., Sun, J. \& Lu, L. 2021. Research on the Multi-Objective Optimization Design of Connecting Claw Jig. International Journal of Steel Structures, 21(6), pp.1911-1920. Available at: https://doi.org/10.1007/s13296-021-00542-6. 


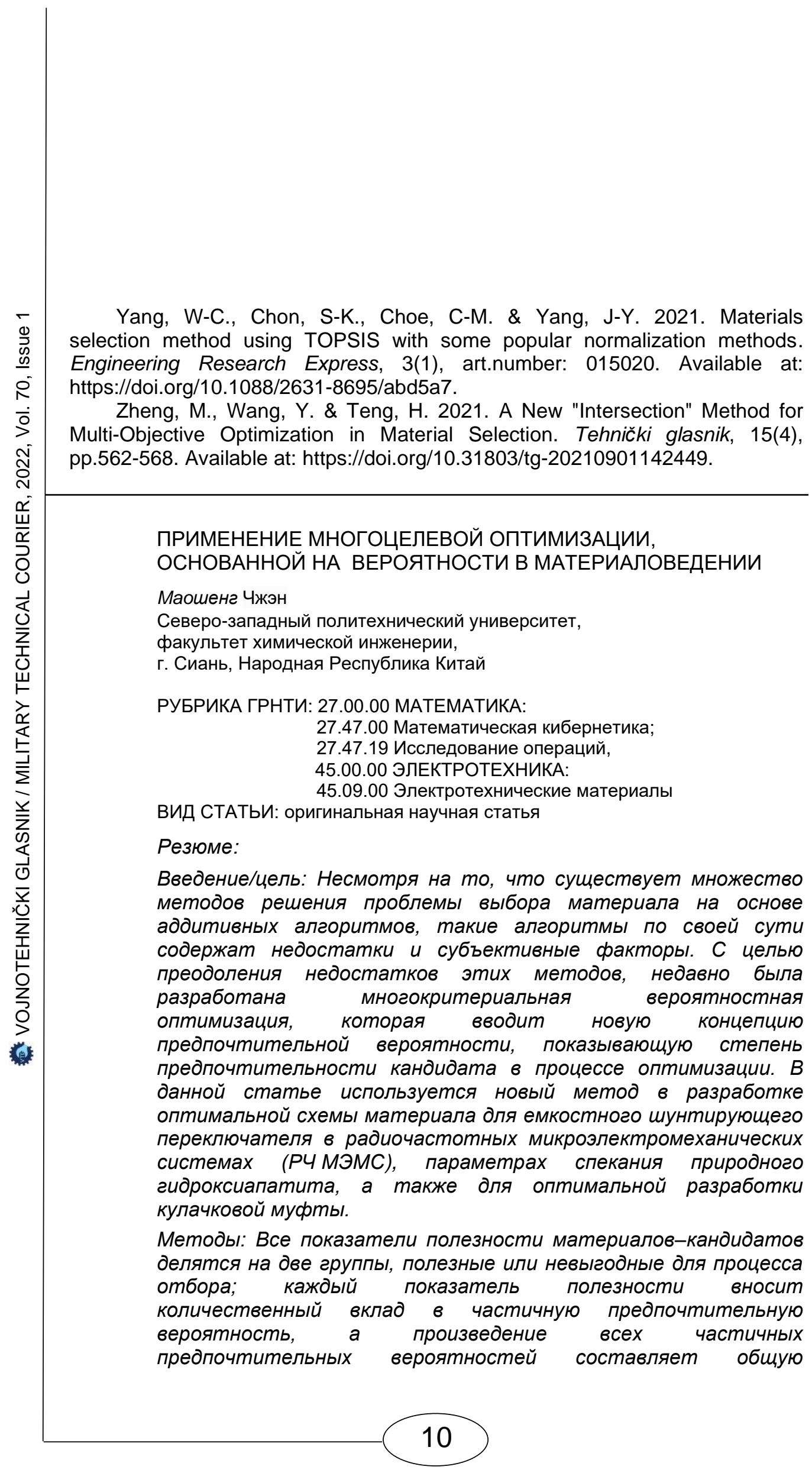


предпочтительную вероятность кандидата, что переводит проблему многокритериальной оптимизации в проблему оптимизации с одним критерием и представляет собой уникальный индекс в процессе конкурсного отбора.

Результаты: Медь оказалась подходящим материалом при выборе материалов для емкостных иунтирующих переключателей в радиочастотных микроэлектромеханических системах (РЧ МЭМС); оптимальные параметры спекания природного гидроксиапатита - $1100^{\circ} \mathrm{C}$ при нулевом давлении сжатия, а оптимальной схемой проектирования кулачковой муфоты является схема №1.

Выводы: Многокритериальная оптимизация на основе вероятностей может широко применяться при принятии объективных решений оптимальных проблем 8 матереаловедении.

Ключевые слова: многокритериальная оптимизация, теория вероятностей, предпочтительная вероятность, материаловедение, выбор схемы.

ПРИМЕНА ВИШЕКРИТЕРИЈУМСКЕ ОПТИМИЗАЦИЈЕ ЗАСНОВАНА НА ВЕРОВАТНОЋИ У ТЕХНОЛОГИЈИ МАТЕРИЈАЛА

Маошенг Џенг

Универзитет Северозапад, Факултет хемијског инжењерства,

Сијан, Народна Република Кина

ОБЛАСТ: математика, материјали

ВРСТА ЧЛАНКА: оригинални научни рад

Сажетак:

Увод/циљ: Иако постоји много метода за решавање проблема селекције материјала заснованих на адитивним алгоритмима, такви алгоритми инхерентно садрже недостатке и субјективне фракторе. Ради превазилажења слабости поменутих метода, недавно је развијена вишекритеријумска оптимизација заснована на вероватноћи која уводи нови концепт пожељне вероватноће који показује степен пожељности кандидата при оптимизацији. У овом раду користи се нов метод за извођење оптималне шеме за материјал за капацитивну склопку шанта у радиофрреквенцијским микроелектромеханичким системима (РФ MEMC), за параметре синтеровања природног хидроксиапатита, као и за оптимално пројектовање канцасте спојнице. 
Meтоде: Сви показатељи перформанси корисности материјала кандидата деле се на корисне и некорисне за селекцију. Сваки показатељ перформанси корисности квантитативно доприноси делимичној пожељној вероватноћи, док производ свих делимичних пожељних вероватноћа чини укупну пожељну вероватноћу кандидата, чиме се проблем вишекритеријумске оптимизације преводи у проблем једнокритеријумске оптимизације $u$ представља јединствени одлучујући индекс у компетитивном процесу селекције.

Резултати: Бакар се показао као одговарајући материјал при селекцији материјала за капацитивне склопке шанта у радиофрреквениијским микроелектромеханичким системима (РФ MEMC). Оптимални параметри синтеровања природног хидроксиапатита су $1100^{\circ} \mathrm{C}$ и нулти притисак сабијања, а оптимална шема за пројектовање канцасте спојнице јесте шема број 1.

Закључак: Вишекритеријумска оптимизација на бази вероватноће може се једноставно применити за објективно решавање оптималног проблема у технологији материјала.

Кључне речи: вишекритеријумска оптимизација, теорија вероватноће, пожељна вероватноћа, технологија материјала, селекција шеме.

Paper received on / Дата получения работы / Датум пријема чланка: 12.12.2021. Manuscript corrections submitted on / Дата получения исправленной версии работы / Датум достављања исправки рукописа: 29.12.2021.

Paper accepted for publishing on / Дата окончательного согласования работы / Датум коначног прихватања чланка за објављивање: 31.12.2021.

(C) 2022 The Author. Published by Vojnotehnički glasnik / Military Technical Courier (www.vtg.mod.gov.rs, втг.мо.упр.срб). This article is an open access article distributed under the terms and conditions of the Creative Commons Attribution license (http://creativecommons.org/licenses/by/3.0/rs/).

( 2022 Автор. Опубликовано в «Военно-технический вестник / Vojnotehnički glasnik / Military Technical Courier» (www.vtg.mod.gov.rs, втг.мо.упр.срб). Данная статья в открытом доступе и распространяется в соответствии с лицензией «Creative Commons» (http://creativecommons.org/licenses/by/3.0/rs/).

(c) 2022 Аутор. Објавио Војнотехнички гласник / Vojnotehnički glasnik / Military Technical Courier (www.vtg.mod.gov.rs, втг.мо.упр.срб). Ово је чланак отвореног приступа и дистрибуира се у складу са Creative Commons licencom (http://creativecommons.org/licenses/by/3.0/rs/). 